\title{
Audit firm tenure and audit qualifications in Spain: a multinomial approach
}

\author{
Josep Garcia-Blandon \\ IQS School of Management, Universitat Ramon Llull \\ Josep Ma Argiles \\ Universitat de Barcelona \\ Monica Martinez-Blasco \\ IQS School of Management, Universitat Ramon Llull
}

Received April 9, 2014; accepted June 20, 2014.

\begin{abstract}
The Green Paper on Audit Policy by the European Commission has questioned the current regulatory framework of audit rotation in the European Union and it has encouraged additional research about the effects of long audit firm tenures on independence. Prior research has mostly limited to examine audit qualifications for reasons of going concern with samples of financially distressed firms. Such approach presents limitations in terms of the generalization of results. The approach we propose allows, on the one hand, for the inclusion of all types of audit qualifications in the analysis; while, on the other hand, it takes into account the particularly serious implications of going-concern qualified opinions for both, the auditor and the audited firm. Our results show that auditors seem willing to sacrifice independence in lengthy engagements, but only regarding non-goingconcern qualified opinions. This result might have some interesting implications for policy makers, particularly in the current discussion about the necessity of mandatory audit firm rotation. If, as most papers do, we measure auditor independence only through the issuance of going-concern opinions, a mandatory firm rotation rule does not seem to be necessary. However, if all types of qualifications are considered, mandatory firm rotation could increase independence.
\end{abstract}

\section{KEYWORDS}

Auditor independence, audit firm tenure, accounting quality, multinomial logistic model, litigation risk. 


\section{Introduction}

As far back as in the early sixties, Mautz and Sharaf (1961) pointed out that extended auditor-client relationships could negatively affect independence, because an auditor's objectivity about a client would be reduced with the passage of time. Since then, lengthy auditor-client relationships have been regarded as a major issue in the conflict of interest faced by the auditor. Long relationships might cause auditor complacency about and possibly complicity in the decisions that management makes regarding the presentation of financial statements (e.g., Shockley, 1982; Myers et al., 2003). As a result, the mandatory rotation of external auditors has long been suggested as a way of strengthening independence. Even though the Sarbanes-Oxley Act did not impose the mandatory rotation of the audit firm, it required a study by the Comptroller General of the United States (GAO, 2003), about the potential effects of imposing the mandatory rotation of auditors. The study did not show a negative effect of extended audit tenures on the quality of financial reports, and thus, it did not recommend rotation. However, the regulator finally established audit rotation at a partner level, which could not provide audit services for the same client for more than five consecutive fiscal years. It also established a minimum five-year time-out period before a partner could re-audit a client. Many countries have adopted similar audit rotation rules. For example, for the year 2008, the 27 States Members of the European Union (EU) were required to adapt national law systems to the revised $8^{\text {th }}$ Company Law Directive (hereinafter, the revised $8^{\text {th }}$ Directive). A main feature of this Directive was to enforce audit rotation at a partner level, although each State Member could voluntarily establish the maximum length of the auditor-client relationship. At present, several maximum periods coexist within the EU: five years in the United Kingdom, six years in France or seven years in Germany and Spain ${ }^{1}$.

Nevertheless, only four years after the approval of the revised $8^{\text {th }}$ Directive in 2006, the European Commission (EC) has explicitly questioned whether the current regulatory framework could sufficiently guarantee independence. In its first paragraph, the Green Paper on Audit Policy states: “(...) limited attention has been given so far to how the audit function could be enhanced in order to contribute to increase financial stability. (...) It seems thus appropriate that both the role of the audit as well as the scope of audit are further discussed and scrutinised in the general context of financial market regulatory reform". One of the major threats to the real independence of external auditors is that mandatory rotation has been established only at a partner level. Regarding this issue, the Green Paper (EC 2010: 11) states: "Situations where a company has appointed the same 
audit firm for decades seem incompatible with desirable standards of independence. Even when "key audit partners" are regularly rotated as currently mandated by the Directive, the threat of familiarity persists. In this context, the mandatory rotation of audit firms not just of audit partners - should be considered". Similarly, in the US, the Public Company Accounting Oversight Board (PCAOB) issued in 2011 a concept release about mandatory audit firm rotation $(\mathrm{PCAOB}, 2011)$ and initiated the process of examining its merits and drawbacks. The main concern, as expressed by PCAOB Chairman Mr. Doty, was about auditors' lack of professional skepticism ${ }^{2}$. The PCAOB is currently considering whether long audit firm tenures align auditors' interests with management instead of protecting investors.

In this article, we examine the effects of audit firm tenure on the likelihood of qualified opinions with a sample of public Spanish companies for the period 2001-2009. This research is mainly motivated by the current regulatory discussion on the convenience of a mandatory audit firm rotation rule. In this line, the EC (2010) Green Paper on Audit Policy has explicitly encouraged additional investigation on auditor independence in EU countries. Moreover, empirical research is not only inconclusive but also refers mainly to the US. Since litigation risk plays a major role in audit literature as a determinant of the auditor reporting decision (e.g., Melumad and Thoman, 1990; Narayanan, 1994), the relatively high-litigation risk of the US makes it difficult to extrapolate results to other settings ${ }^{3}$. In addition, most previous research has limited to examine the effects of tenure on the issuance of going-concern modified opinions (GCMO) to financially distressed firms. This approach presents, in our view, two shortcomings. Firstly, financially distressed firms are not representative of the population of audited firms and the same can be said of GCMO with respect to the whole universe of audit qualifications. Therefore, results are difficult to be generalized, either to the whole population of firms or to the whole universe of qualifications. Secondly, focusing exclusively on GCMO does not account for the traditional role of the auditor in the corporate governance scheme, as information verifiers (Simunic, 1984). Nevertheless, when auditors issue GCMO, they do not perform this information verifier role, but act as substitutes of bankruptcy prediction models. On the other hand, the few articles that have included all types of qualifications and firms in the analysis (Vanstraelen, 2000; and Ruiz-Barbadillo et al., 2005), have failed to account for the particularly serious implications of GCMO for both, auditor and client. 
We contribute to the literature by providing a new framework which overcomes the abovementioned shortcomings. The multinomial logistic approach we propose allows to include all types of qualification into the analysis, but at the same time, acknowledges for the different implications of different types of audit qualifications. A second contribution is that for the first time in the literature, accounting quality is included as a determinant of audit qualifications. We consider this an important issue, because without including accounting quality in the analysis, any reported negative effect of tenure on audit qualifications (as for example in Vanstraelen, 2000) could mean either loss of independence with tenure, or higher accounting quality (and thus, lower likelihood of audit qualifications) with tenure. Evidently, the regulatory implications of each situation would be opposite.

Our results show that long tenures make non going-concern modified opinions (NGCMO) less likely, while do not affect GCMO. This finding highlights the limitations of the general approach followed in the literature to capture the loss of independence through the issuance of GCMO to financially distressed firms.

The remainder of the paper is organized as follows. In section two, we review the literature on the association between tenure and audit quality. Section three summarizes the regulation of the auditor-client relationship in the Spanish market. In section four we define our model and describe our dataset. Results are discussed in sections five and six. Finally, conclusions are presented in section seven.

\section{Review of the literature}

The issuance of qualified audit reports has been used in the literature as a proxy of auditor independence. The rationale of this approach would be that since the probability of switching the audit firm increases after a qualified report (e.g., Krishnan, 1994; Lennox, 2000), qualified opinions suggest an exercise of independence by the external auditor. Therefore, following Shockley's (1982) concerns about the negative effects of tenure on independence, we should expect a lower likelihood of qualified reports in lengthy auditorclient relationships. Empirical research, though particularly prolific during the last two decades, does not support that independence would be threatened by long tenures. Louwers (1998) and Carcello and Neal (2000), with samples of US financially distressed firms, did not find a negative effect of tenure on the auditors' reporting decision. A similar conclusion was reached by Vanstraelen (2002) and Knechel and Vanstraelen (2007) for 
the Belgian market, and by Ruiz-Barbadillo et al. (2004) and (2006) for the Spanish market. This evidence supports that the litigation risk faced by the auditor when an unqualified report is issued to a company which deserves an audit report with GCMO would offset the 'familiarity threat' associated to long tenures with the audit firm. However, more recent research has provided somewhat contradictory results. Lim and Tan (2010) reported a positive effect of tenure on audit quality. The authors measured audit quality through several proxies, including the propensity for auditors to issue GCMO to financially distressed firms. Conversely, Gul et al. (2011) for the US and Firth et al. (2012) for China, concluded that auditors were willing to forgo their independence by issuing fewer going-concern reports when auditor tenure was long. Without limiting the analysis to financially distressed companies or to GCMO, while Vanstraelen (2000) reported that long tenures significantly increased the likelihood of unqualified audit reports in the Belgian market, Ruiz-Barbadillo et al. (2005) found that GCMO were more likely in longer tenures in Spain.

With the only exception of Vanstraelen (2000), the effects of tenure on the likelihood of qualified reports have been studied in the context of GCMO and financially distressed firms. Such approach faces a serious shortcoming regarding the generalization of the reported results. Financially distressed firms are not representative of the total population of audited firms, and the same can be said regarding GCMO with respect to the whole universe of audit qualifications. Therefore, results reported by previous research are difficult to be generalized either to the whole population of firms, or to the whole universe of audit qualifications. On the other hand, results reported by Vanstraelen (2000), although more generalizable because of the inclusion of all type of audit qualifications and firms, do not differentiate between GCMO and other types of qualified opinions. This distinction is meaningful becausefirstly, GCMO and NGCMO represent different dimensions of the audit activity; and secondly, GCMO involve relatively higher levels of litigation risk compared with NGCMO. Regarding the first issue, as posed by Simunic (1984), the auditors' traditional role in the corporate governance scheme is to verify the information produced by managers. However, when auditors issue a qualified report for reasons of going concern, they are not performing the information verifier role, but acting as a substitute of bankruptcy prediction models ${ }^{4}$. Regarding the different levels of litigation risk of GCMO and NGCMO, the decision of issuing a qualified opinion is influenced by the perceived consequences in the economic trade-off between the expected cost of the potential loss of a client, on the one hand, and the probability of being exposed 
to third-party lawsuits and loss of reputation, on the other. The risk of litigation faced by the auditor is particularly high when it fails to issue a GCMO to a company that subsequently goes bankrupt [e.g., Palmrose 1987; Krishnan and Krishnan, 1997]. Therefore, Vanstraelen's (2000) approach fails to account for the different levels of litigation risk of GCMO and NGCMO. If, for example, auditors were willing to forego independence regarding relatively low risky NGCMO but not regarding comparatively riskier GCMO, the inclusion of the two types of audit qualifications into a single variable could cause misleading results.

\section{Audit regulation in Spain}

With the main goals of enhancing transparency and making financial statements more comparable internationally, the first audit law in Spain was enforced in 1988 as a result of the implementation of the $8^{\text {th }}$ Directive on Company Law. Following the approval of the Spanish Audit Law, companies above a certain size were required to appoint an external auditor to issue a report about the company's financial statements. The law imposed some conditions to regulate the auditor-client relationship in order to strengthen independence. For example, a multi-year contract with the audit firm, with duration between three and nine years, was established. It also imposed the mandatory rotation of the audit firm since, independently of the length of the initial contract, the same audit firm could not be reappointed. Nevertheless, as a result of a subsequent legal reform, both the maximum limit in the number of consecutive years to be audited by the same firm and the prohibition to reappoint the audit firm were abolished in 1995. After this reform, auditors could be engaged for an initial period ranging between a minimum of three and a maximum of nine years, but after the expiration of the initial contract the company could renew the contract with the same auditor on a yearly basis. The 1988 Spanish Audit Law imposed the mandatory rotation of the audit firm after nine years, being 1988 the first year to be subject to the mandatory rotation rule. Thus, 1997 would have been the first year in which those companies which had not changed the audit firm since 1988 would have to. However, since the rotation rule was removed in March 1995, it was in fact never applied.

With the same aim as the Sarbanes-Oxley Act in the US, the Spanish Financial Law was passed in 2002 as a reaction to corporate financial scandals. An amendment was included during the Law's approval process including the mandatory rotation of the audit firm, 
after a maximum period of twelve years. Besides, a minimum three-year period was required to re-hire the audit firm. Similarly to the 1995 reform avoiding mandatory rotation, largely the result of pressures induced by audit firms, this amendment led to strong criticism from the auditing profession, which caused its eventual withdrawal. Finally, mandatory rotation was limited to change the audit team after seven years, but not the audit firm. The maximum partner tenure of seven years has also been maintained by the 2010 reform of the Spanish Audit Law, however, without imposing the rotation of the audit team ${ }^{5}$.

\section{Methodology}

\subsection{Research design and hypothesis development}

This research addresses the effects of tenure on auditors' independence, measuring independence through the ability of the auditor to issue qualified audit reports. The approach we propose extends prior research as it allows, on the one hand, to include all types of audit qualifications in the analysis while, on the other hand, to account for the potentially different implications of GCMO and NGCMO.

As discussed in section two, prior research has generally measured auditor independence through the issuance of GCMO to financially distressed companies. The election of GCMO as a proxy of independence is generally justified on the grounds that available evidence (e.g., Chow and Rice, 1982 and Krishnan, 1994 for the US; Craswell, 1988 for Australia) supports the view that the probability of switching audit firms is higher following the issuance of a qualified opinion. Similarly, Ball et al. (1979) argued that auditors were reluctant to qualify their reports, since the publication of audit qualifications would adversely affect the interests of corporate participants, and Levinthal and Fichman (1988) claimed that a qualified opinion is an indicator of conflict within the auditor-client relationship. Besides, audit qualifications have negative effects for the audited company in terms of negative stock price reactions (Chow and Rice, 1982b; Dopuch et al., 1987; Loudder et al., 1992; and Ameen et al., 1994), lower market responses to earnings announcements (Choi and Jeter, 1992) and higher costs of debt (Chen et al., 2012). However, all the above-mentioned articles do not limit the analysis to GCMO, but include all types of audit qualifications. Therefore, empirical evidence supports the use of all types of audit qualifications (not only GCMO) as a proxy for independence. Nevertheless, the results by Krishnan (1994) support the necessity to 
differentiate between GCMO and NGCMO. The author reported that although auditor switching significantly increased after both GCMO and NGCMO, the switching rate was almost double for GCMO than for NGCMO.

Accordingly, the research question states:

Does the likelihood of qualified audit reports decrease with tenure?

Based on the concerns expressed by the Green Paper on Audit Policy about the effects of long tenures on independence; the results of Vanstraelen (2000) in a low litigation risk country; and considering the relatively low litigation risk profile of the Spanish audit market, we expect a higher likelihood of unqualified audit reports in longer tenures.

Therefore, we hypothesize that:

Hypothesis 1: ceteris paribus, the longer the auditor-client relationship, the less likely the issuance of 'unclean' audit reports (qualified opinion, adverse opinion or disclaimer of opinion).

Litigation risk constitutes a major motivation in the auditor reporting decision. According to our discussion in section two, this risk is particularly high when the auditor fails to issue a GCMO to a company that subsequently goes bankrupt. Thus, auditors will be expected to be less willing to compromise their independence regarding GCMO compared with NGCMO. Therefore, we hypothesize that:

Hypothesis 2: the loss of independence in lengthy audit engagements should be lower regarding the issuance of GCMO compared to NGCMO.

Prior research on the effects of tenure on the likelihood of audit qualifications has been carried out through the classical logistic regression approach (e.g., Vanstraelen, 2000; Ruiz-Barbadillo et al., 2004, 2005; Knechel and Vanstraelen, 2007) with a dependent binary variable coded 0 in case of an unqualified audit report and coded 1 in case of an 'unclean' report. While most papers only account for GCMO, when this is not the case, all types of audit qualification are coded 1, independently of their nature. In such cases, the different implications of the two types of audit qualifications are not properly addressed. In order to overcome this limitation we follow a multinomial logistic approach in which, the dependent variable is coded 0 in case of an unqualified report; coded 1 in case of NGCMO; and coded 2 in case of $\mathrm{GCMO}^{6}$. The experimental variable is the length of the auditor-client relationship. Control variables are similar to the ones used in prior research as determinants of the auditor's reporting behavior (particularly in DeFond et al., 2002 and Carey and Simnett, 2006). In addition, we also include an independent 
variable accounting for periods of economic downturns as a determinant of the auditor's reporting decision.

Accordingly, we propose the following model to carry out the multinomial analysis.

Model 1:

OPINION = $\mathrm{f}($ PBANK, SIZE, LEVERAGE, LIQUIDITY, STOCKS, LOSSES, AUDFIRM, CRISIS, TENURE), where:

Dependent variable:

OPINION is the variable accounting for the auditor's opinion: unqualified (coded 0 ), NGCMO (coded 1), and GCMO (coded 2).

Experimental variable:

TENURE is the natural log of the number of consecutive years the company has been audited by the same firm.

Control variables:

PBANK is probability of bankruptcy as measured by adjusted Zmijewski (1984) score, with the weights proposed by Carcello et al. (1995).

SIZE is the natural log of the firm's total assets in book values at the end of the year as a proxy for firm size.

LEVERAGE is the firm's level of financial leverage calculated as total debt divided by total equity, both in book values, at the end of the year.

LIQUIDITY is a measure of the firm's liquidity at the end of the year, calculated as the sum of its cash positions divided between its current liabilities.

STOCKS are computed as the firm's inventories divided by total assets at the end of the year, both in book values.

LOSSES is a binary variable with score 1 if the company's net profit on year $t$ is negative and 0 otherwise.

$A U D F I R M$ is a binary variable with score 1 if the company is audited by a non-Big 4 audit firm and 0 otherwise.

CRISIS is a binary variable with score 1 for years 2001, 2002, 2008 and 2009, and 0 otherwise. Years 2001 and 2002 correspond to the dotcom crisis, while years 2008 and 2009 indicate the beginning of the financial crisis. 
Next, we discuss the expected effects of control variables on the probability of 'unclean' audit reports.

PBANK measures the probability of bankruptcy based on Zmijewski (1984), where higher values indicate a greater probability of bankruptcy, and therefore higher litigation risk for the incumbent auditor. Thus, we expect a positive effect of $P B A N K$ on the likelihood of audit qualifications. Since previous research (e.g., Lys and Watts, 1994; Shu, 2000) has documented a positive relationship between the size of the audited firm and litigation costs, the probability of qualified reports should be higher for large firms. Nevertheless, DeAngelo (1981) pointed out that auditors' incentives to compromise independence were a function of client importance. As litigation risk is relatively low in the Spanish audit market, we predict a negative effect of SIZE on the probability of qualified reports. Financial leverage increases the probability of bankruptcy, and consequently raises litigation risk. Accordingly, we expect a positive effect of $L E V E R A G E$ on the likelihood of audit qualifications. Liquidity has been usually found a significant determinant in predicting bankruptcy (e.g., Hopwood et al., 1989). Therefore, poor liquidity is expected to increase the likelihood of qualified reports since it increases auditor's litigation risk. In addition, firms with liquidity problems might be more willing to manipulate financial statements (e.g., Butler et al., 2004), thus making audit qualifications more likely. Therefore, a negative coefficient is expected for variable LIQUIDITY. The auditing of the company's inventories may represent serious difficulties, because it involves two audit assertions: valuation and completeness (McDaniels, 1990). Consequently, as posed by Simunic (1980), audit fees are higher for those firms with relatively large amounts of inventories. In addition, audit errors (Firth, 2002) and lawsuits against auditors (St. Pierre and Anderson, 1984) are also often caused by inventories. Accordingly, we hypothesize a positive effect of inventories on the probability of NGCMO, and therefore a positive coefficient for variable $S T O C K S$ regarding NGCMO. However, we do not expect a significant effect of inventories on the issuance of GCMO. Following previous research (e.g., Dopuch et al., 1987; Firth, 2002) companies suffering losses should face higher probabilities of having qualified reports. The explanation is quite straightforward and similar to the one proposed to justify the expected negative relationship between liquidity and audit qualifications. Within the litigation risk framework, since litigation risk is higher when auditing firms with losses, so it should be the probability of audit qualifications. In addition, firms experiencing losses will more likely incur in earnings management activities, therefore making audit qualifications more likely.AUDFIRM 
accounts for a potential lower propensity of qualified reports by non-big 4 auditors.As the risk of bankruptcy is particularly high during periods of economic downturns, we include the variable CRISIS to account for the differential levels of litigation risk during these periods. We expect a positive effect of periods of crisis on the likelihood of audit qualifications.

\subsection{Sample and dataset}

Empirical analysis is performed on the basis of all the companies quoted in the Spanish Stock Exchange (Sistema de InterconexiónBursátilEspañol) during the research period 2001-2009. Data about the independent variables in the model are provided by Thomsom Reuters Knowledge. Regarding the nature of audit reports, information is provided by the ComisiónNacional del Mercado de Valores (CNMV). Our model includes liquidity and debt ratios among the explanatory variables. Thus, following prior research, banks and financial companies are removed from the sample. Our dataset is formed by 112 firms. Considering the nine-year research period, that makes 1008 firm-year observations. Nevertheless, in 127 cases information about at least one variable in our model was not available. Therefore, our sample is finally formed by 881 firm-year observations.

According to the Spanish legislation, the audit report has to include the opinion of the auditor about the firm's accounting reports. This can be: unqualified, qualified, unfavorable or disclaimer of opinion. Nevertheless, audit reports with unfavorable or disclaimer of opinion are in practice very unusual in Spain, at least for quoted companies. In this research, we examine 881 audit reports, 758 of them with an unqualified opinion and 123 with a qualified opinion. GCMO are relatively scarce in our research period: only in 19 out of the 123 qualified audit reports, qualifications were for reasons of going concern. Finally, none of the 881 audit reports showed an unfavorable or disclaimer of opinion.

The supervisor of the Spanish stock market (CNMV, 2009) classifies audit qualifications into two major groups: quantified and unquantified. In addition, quantified qualifications are also classified into two subgroups, depending on whether they affect profit and losses or equity. Similarly, unquantified qualifications are also classified in 'Uncertainty and others' and 'Limitations'. Among qualifications due to uncertainties, the most serious are those concerning the continuation of business, the so-called GCMO, in which the auditor expresses doubts about the ability of the company to continue doing business. However, uncertainties can also have less dramatic effects; for example, they might be associated 
with the firm's ability to recover some tax credits. On the other hand, qualifications for limitations on scope show that the auditor has not had enough information to apply the procedures required by the technical auditing standards. Therefore, while GCMO are issued when the auditor has doubts about the future of the company and have little to do with the firm's accounting quality, NGCMO would be indicators of low accounting quality.

In table 1 we show the 881 audit reports classified by year and type of opinion, in percentage of total reports of each year.

\begin{tabular}{|l|c|c|c|c|c|c|c|c|c|}
\hline $\begin{array}{l}\text { Auditor } \\
\text { Opinion }\end{array}$ & $\mathbf{2 0 0 1}$ & $\mathbf{2 0 0 2}$ & $\mathbf{2 0 0 3}$ & $\mathbf{2 0 0 4}$ & $\mathbf{2 0 0 5}$ & $\mathbf{2 0 0 6}$ & $\mathbf{2 0 0 7}$ & $\mathbf{2 0 0 8}$ & $\mathbf{2 0 0 9}$ \\
\hline Unqualified & $79 \%$ & $82 \%$ & $86 \%$ & $87 \%$ & $91 \%$ & $92 \%$ & $90 \%$ & $82 \%$ & $82 \%$ \\
\hline NGCMO & $21 \%$ & $17 \%$ & $14 \%$ & $13 \%$ & $8 \%$ & $7 \%$ & $10 \%$ & $10 \%$ & $11 \%$ \\
\hline GCMO & $0 \%$ & $1 \%$ & $0 \%$ & $0 \%$ & $1 \%$ & $1 \%$ & $0 \%$ & $9 \%$ & $7 \%$ \\
\hline $\begin{array}{l}\text { Number of } \\
\text { Reports }\end{array}$ & 80 & 89 & 92 & 102 & 103 & 105 & 104 & 104 & 102 \\
\hline
\end{tabular}

Table 1. Classification of audit reports by year and auditor opinion

The percentage of unqualified reports steadily increases during the subperiod 2001-2006 and decreases afterwards. The maximum value corresponds to year 2006 , when $92 \%$ of the total reports are unqualified. Since GCMO were very rare before the financial crisis, the rise of unqualified reports in the 2001-2006 subperiod strongly corresponds to a fall of NGCMO. However, after 2007, while the number of NGCMO remains stable, GCMO show a dramatic surge. Thus, the fall of unqualified reports during the financial crisis is caused by the increase of NGCMO.

Table 2 shows some descriptive statistics about independent variables. The average company SIZE is 6.67 , corresponding to total assets of 4.7 billion of euros. The statistics for variable $L E V E R A G E$ indicate that for the companies in our sample, on mean terms, the amount of debt is four times the amount of equity. Regarding LIQUIDITY, firms' cash positions represent $18 \%$ of current liabilities, on mean terms. STOCKS account, on average, for the $16 \%$ of firms' total assets. In one company, however, this percentage increases up to $97 \%$. The mean value of 0.16 for variable LOSSESindicates that companies with negative net income account for the $16 \%$ of our dataset. The table also shows the extreme level of concentration of the Spanish audit market by Big 4 firms, as companies audited by non-Big 4 auditors only represent seven percent of the sample. 
Regarding our main variable of interest, TENURE, auditor-client relationships in our dataset show an average duration of nine years, with a maximum value of 23 years.

\begin{tabular}{|l|c|c|c|c|c|}
\hline Variable & MEAN & MEDIAN & $\begin{array}{c}\text { ST. } \\
\text { DEV. }\end{array}$ & MAXIMUM & MINIMUM \\
\hline PBANK & -1.70 & -1.58 & 4.34 & 79.56 & -67.05 \\
\hline SIZE & 6.67 & 6.47 & 1.85 & 11.6 & 0.10 \\
\hline LEVERAGE & 4.16 & 1.91 & 31.63 & 922.77 & 0.00 \\
\hline LIQUIDITY & 0.18 & 0.08 & 0.32 & 5.55 & 0.00 \\
\hline STOCKS & 0.16 & 0.11 & 0.18 & 0.97 & 0.00 \\
\hline LOSSES & 0.16 & 0.00 & 0.37 & 1.00 & 0.00 \\
\hline AUDFIRM & 0.07 & 0.00 & 0.26 & 1.00 & 0.00 \\
\hline CRISIS & 0.42 & 0.00 & 0.49 & 1.00 & 0.00 \\
\hline $\begin{array}{l}\text { TENURE } \\
\text { (in years) }\end{array}$ & 9.26 & 9.00 & 5.79 & 23 & 1.00 \\
\hline
\end{tabular}

Table 2. Descriptive statistics

PBANK is probability of bankruptcy as measured by adjusted Zmijewski (1984) score, with the weights proposed by Carcello et al. (1995).

SIZE is the natural log of the firm's total assets in book values at the end of the year as a proxy for firm size.

LEVERAGE is the firm's level of financial leverage calculated as total debt divided by total equity, both in book values at the end of the year.

LIQUIDITY is a measure of the firm's liquidity at the end of the year, calculated as the sum of its cash positions divided between its current liabilities.

STOCKS are computed as the firm's inventories divided by total assets at the end of the year, both in book values.

LOSSES is a binary variable with score 1 if the company's net profit on year $\mathrm{t}$ is negative and 0 otherwise.

$A U D F I R M$ is a binary variable with score 1 if the company is audited by a non-Big 4 audit firm and 0 otherwise.

CRISIS is a binary variable with score 1 for years 2001, 2002, 2008 and 2009, and 0 otherwise. Years 2001 and 2002 correspond to the dotcom crisis, while years 2008 and 2009 indicate the contemporary financial crisis.

TENURE is the natural log of the number of consecutive years the company has been audited by the same firm. 
Graph 1 shows the histogram of the number of consecutive years a firm has been audited by the same audit firm. As can be seen, the distribution is far from normal. Our sample is characterized by a relatively high concentration of firms in the two extremes of the variable. It therefore supports our definition of variable TENURE in natural log terms.

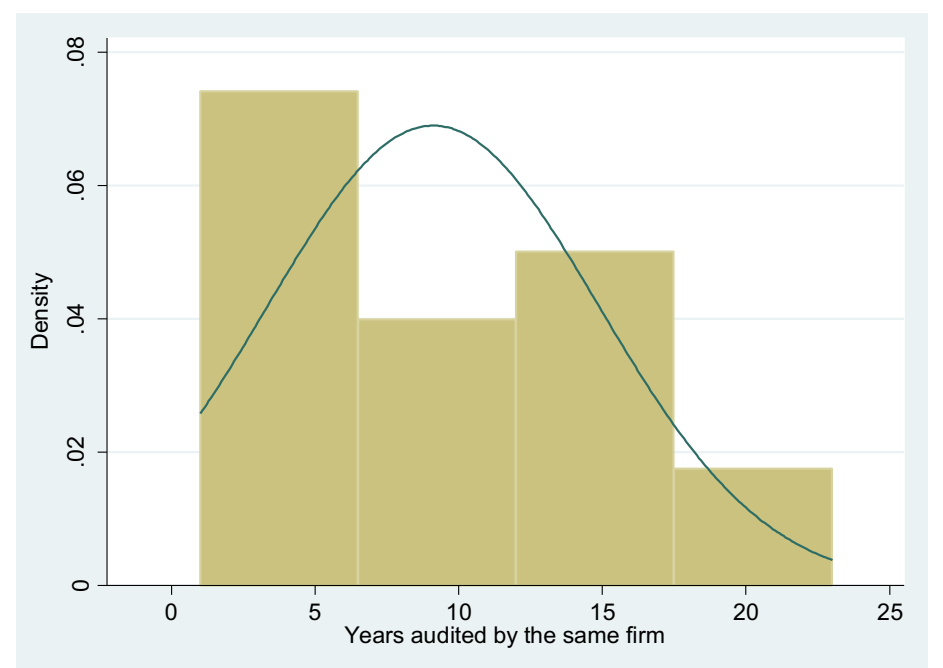

Figure 1. Histogram of audit tenure

Table 3 shows Pearson's correlation coefficients, with significance levels, for the independent variables in the model. Variable SIZE shows the strongest levels of correlation with the remaining independent variables. Interestingly, the positive correlation with TENURE shows that larger companies tend to engage in lengthier audit contracts. Similarly, the negative correlation between TENURE and LOSSES indicates that firms with losses show relatively short-term audit engagements. Finally, firms audited by non-Big 4 auditors are relatively smaller and tend to show shorter tenures. Since correlation coefficients are rather low (a maximum of 0.28 in absolute values), multicollinearity will hardly affect our estimation. Nevertheless, variance inflation factors (VIF) have been calculated to rule out the negative potential effects of multicollinearity in our results. As expected, VIF (not reported) are rather low (the maximum value is 1.21 for variable SIZE), thus supporting our initial opinion that multicollinearity will not affect our results. 


\begin{tabular}{|l|c|c|c|c|c|c|c|c|}
\hline & PBANK & SIZE & LEVERAGE & LIQUIDITY & STOCKS & LOSSES & AUDFIRM & CRISIS \\
\hline PBANK & 1 & & & & & & & \\
\hline SIZE & $0.208^{*}$ & 1 & & & & & & \\
\hline LEVERAGE & $0.283^{*}$ & 0.004 & 1 & & & & & \\
\hline LIQUIDITY & $-0.101^{*}$ & $-0.101^{*}$ & -0.024 & 1 & & & & \\
\hline STOCKS & $-0.261^{*}$ & $-0.261^{*}$ & 0.006 & $-0.165^{*}$ & 1 & & & \\
\hline LOSSES & $0.145^{*}$ & $-0.167^{*}$ & 0.018 & 0.047 & $0.157^{*}$ & 1 & & \\
\hline AUDFIRM & 0.042 & $-0.224^{*}$ & -0.002 & 0.032 & $0.183^{*}$ & $0.123^{*}$ & & 1 \\
\hline CRISIS & -0.003 & 0.037 & 0.052 & -0.030 & 0.008 & $0.157^{*}$ & 0.007 & 1 \\
\hline TENURE & $-0.037^{*}$ & $0.176^{*}$ & -0.050 & 0.013 & $-0.134^{*}$ & $-0.143^{*}$ & $-0.220^{*}$ & 0.050 \\
\hline
\end{tabular}

*Significant at the $1 \%$ level

Table 3. Pearson correlations between independent variables

\section{Results}

Firstly, we present and discuss the results of the univariate analysis and afterwards we address the results of the multivariate analysis.

\subsection{Univariate analysis}

We perform a univariate analysis of differences of means for the three groups of firms according with the nature of the audit report: unqualified; NGCMO and GCMO. As expected, the Shapiro-Wilk test rejects the hypothesis of normality for each independent variable. Thus, the Mann-Whitney test of differences of medians is performed in order to assess the statistical significance of these differences. Median values of independent variables for each subsample, and significance levels from the Mann-Whitney test for the continuous variables and the Pearson chi-square test for the dichotomous variables LOSSES, AUDFIRM and CRISIS, are shown in table 4. 


\begin{tabular}{|l|c|c|c|}
\hline Variable & UNQUALIFIED & NGCMO & GCMO \\
\hline PBANK & -1.78 & -1.24 & $0.50^{*}$ \\
\hline SIZE & 6.57 & $5.83^{*}$ & 6.74 \\
\hline LEVERAGE & 1.88 & 1.84 & $5.21^{*}$ \\
\hline LIQUIDITY & 0.09 & $0.05^{*}$ & $0.01^{*}$ \\
\hline STOCKS & 0.11 & 0.12 & $0.20^{*}$ \\
\hline LOSSES & 0.13 & $0.28^{*}$ & $0.89^{*}$ \\
\hline AUDFIRM & 0.07 & 0.06 & 0.11 \\
\hline CRISIS (in & 0.40 & 0.51 & $0.89^{*}$ \\
\hline $\begin{array}{l}\text { TENURE } \\
\text { years) }\end{array}$ & 9.00 & $6.00^{*}$ & 4.00 \\
\hline
\end{tabular}

* Significant at the $1 \%$ level

Table 4. Median values of independent variables according with auditor opinion. (For non-continuous variables LOSSES and CRISIS mean values instead of medians have been provided)

Results from table 4 strongly fit our expectations. Regarding our experimental variable TENURE, firms with qualified reports (either GCMO or NGCMO) show shorter audit tenures compared with firms with unqualified reports, although only for the NGCMO subsample is this difference statistically significant. Thus, the univariate analysis seems to support a negative effect of tenure on auditor independence, although only regarding NGCMO. Results concerning control variables indicate that firms with GCMO show significantly higher probability of bankruptcy, higher levels of financial leverage and inventories and lower levels of liquidity. On the other hand, those firms NGCMO are relatively smaller and, similarly to the going-concern subsample, they also show lower levels of liquidity. Audit qualifications, both GCMO and NGCMO, are positively associated to the reporting of losses. Finally, audit qualifications are more frequent during economic downturns, although only for the GCMO subsample is this difference statistically significant.

\subsection{Multivariate analysis}

The joint effect of tenure and the proposed control variables on the likelihood of audit qualifications is addressed through a pooled multinomial logistic regression. As expected, heteroskedasticityis detected in our data, thus reported $z$-values are calculated with robust standard errors. Following post-estimation analyses based on bivariate models, four influential observations were identified (with Pregibondbeta higher than 0.2). Results 
reported in table 5 are obtained after the re-estimation of the model without these influential observations. Table 5 reports estimations for NGCMO and GCMO; being firms with unqualified reports the comparison group.

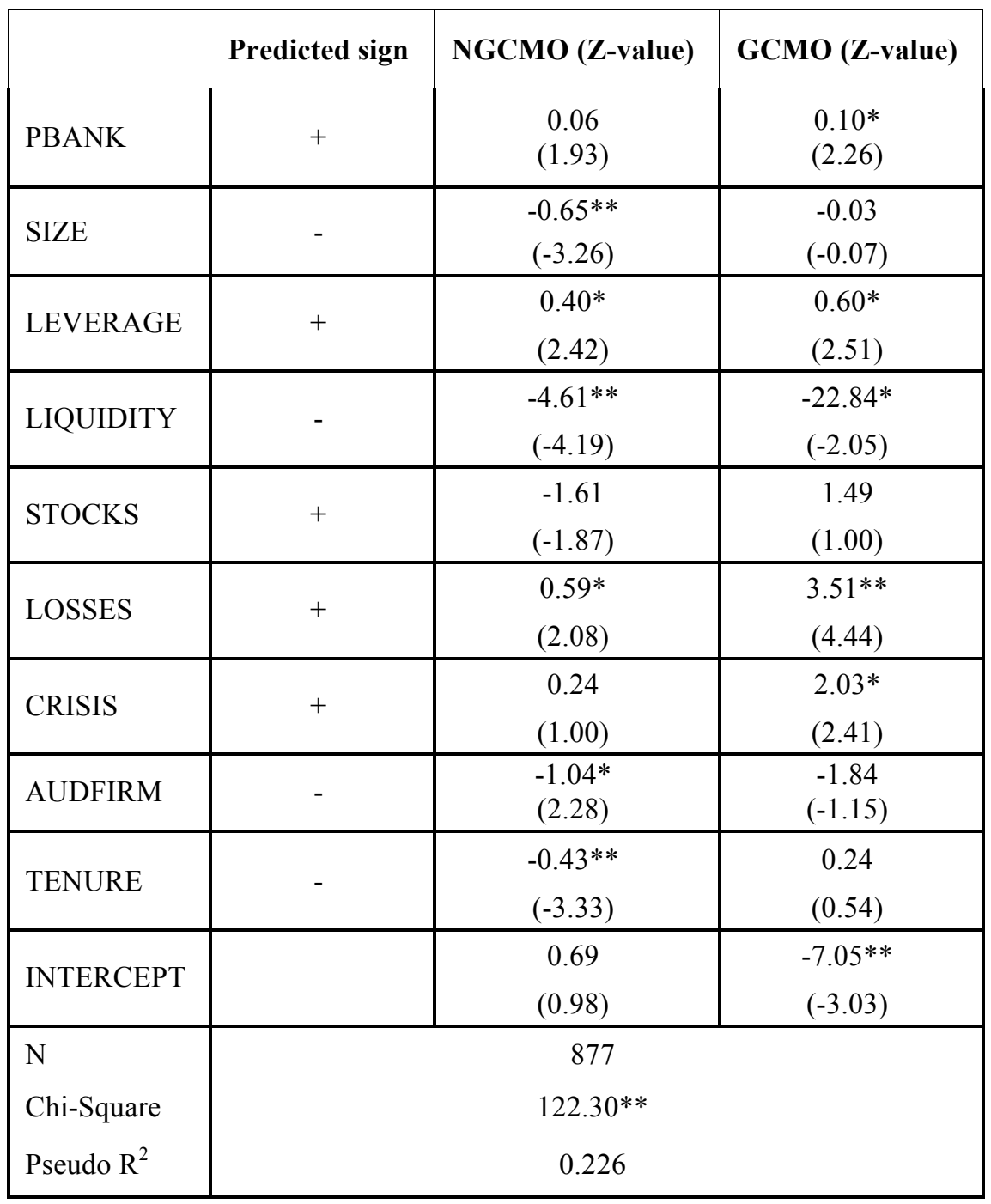

$*, * *$ Significant at the 5 percent and 1 percent levels, respectively

Table 5. Regressions results on the association of tenure with auditor's opinion

Based on the likelihood ratio Chi-square test, the null hypothesis that all predictors' regression coefficients in the model are simultaneously zero is rejected. According to the McFadden's pseudo $\mathrm{R}^{2}$, our model explains $23 \%$ of the total variance. A main issue regarding multinomial logistic models is whether some categories of the dependent variable could be combined into a single one. To address this question properly, we perform a log-likelihood ratio test for combining dependent categories. Our main interest is to check if the two categories of audit qualifications, GCMO and NGCMO, could be combined into a single category. In all three possible combinations: 'unqualified versus 
NGCMO'; 'unqualified versus GCMO' and 'NGCMO versus GCMO', the null hypothesis that the specified categories are indistinguishable with respect to the variables in the model is rejected (P-Value $<0.01$ ). This result supports our choice of a multinomial logistic model over the traditional bivariate approach.

We are primarily concerned with the sign and statistical significance of the coefficients of TENURE. If lengthy auditor-client relationships impair independence, the coefficient should be negative and statistically significant. As shown by table 5 , this is the case regarding NGCMO, but not regarding GCMO. In the first case, TENURE shows a negative and statistically significant coefficient $(P$-Value $<0.01)$, while in the second case the coefficient is positive, although non-significant. Therefore, regarding the two hypotheses posed in section 4, hypothesis 1 stating that longer auditor-client relationships make 'unclean' reports less likely is rejected for GCMO but not for NGCMO. Therefore, as regards hypothesis 2, affirming that auditors would be less willing to compromise independence regarding the issuance of GCMO compared to NGCMO, it cannot be rejected. Taken together these results suggest that external auditors seem willing to sacrifice independence in lengthy engagements, but only regarding the issuance of NGCMO. Following our discussion in section 4, the different results regarding both types of audit qualifications could be explained by the higher risk of litigation associated to GCMO compared to NGCMO. This result had been anticipated by the univariate analysis. Evidence reported about the lack of a negative effect of tenure on independence measured through GCMO supports available evidence for the Spanish market (Ruiz-Barbadillo et al., 2004 and 2006).

Results regardingcontrol variables show that, in all cases, when a significance effect is reported it shows the predicted direction. $P B A N K$ is statistically significant regarding GCMO $(P$-Value $<0.05)$ and marginally significance for NGCMO, in both cases with a positive sign. SIZEhas a negative effect on the likelihood of NGCMO $(P$-Value $<0.01)$, while it does not affect GCMO. This result puts forward that the economic incentives of the auditor with the audited company more than offset the potential increase in litigation costs faced with large clients, regarding the issuance of NGCMO. The lack of significance of SIZE regarding GCMO would suggest that, even in the low litigation risk Spanish audit market, while auditors would be willing to impair independence with large and, presumably,more rewarding clients, regarding relatively low litigation risk NGCMO; they would not do it about high litigation risk GCMO. As expected, financial leverage positively affects the issuance of audit qualifications. Coefficients of LEVERAGE are 
negative and statistically significant for both NGCMO and GCMO (P-Value $<0.05)$. Following our expectations, the likelihood of qualified reports decreases with the firms' cash positions. LIQUIDITY shows negative and significant ( $P$-Value $<0.01$ for NGCMO and $<0.05$ for GCMO) coefficients regarding both types of qualified opinions. As predicted, both types of qualified opinions are more likely when firms report ordinary losses. Coefficients associated to LOSSES are positive and statistically significant $(P$ Value $<0.05$ for NGCMO and $<0.01$ for GCMO). Being audited by a Big 4 firm makes NGCMO more likely, while it does not affect GCMO. This would suggest that non-Big 4 auditors would be more willing to impair independent in lengthy engagements regarding relatively low risky NGCMO but not regarding GCMO. Also as expected, the likelihood of GCMO increases during economic downturns (P-Value <0.05). However, the effect of CRISIS on NGCMO, although positive, is non-significant. From our discussion in section 4 we had assumed positive coefficients associated to STOCKS regarding NGCMO. However, the coefficient isnegative and marginally significant.

We check the robustness of results to a different measure of audit tenure. Accordingly, we define the dichotomic variable LONGTENURE coded 1 when audit tenure was above the median value and zero otherwise. Afterwards, we re-estimate model 1 with LONGTENURE instead of the original variable TENURE. Results (not provided) remain largely unchanged. The new variable LONGTENURE shows a negative and statistically significant coefficient $(P$-Value $<0.01)$. Coefficients of control variables show in all cases the same signs and levels of significance as those reported in table 5.

There is some evidence (Levinthal and Fichman, 1988; Vanstraelen, 2000) that auditors are more willing to issue unqualified reports during the first two years of engagement (the so-called 'honeymoon' period). To test this effect, we re-estimate our model including HONEYMOON, a dichotomous variable with score 1 for the first and second year of the audit contract and 0 otherwise, among the explanatory variables. Under a 'honeymoon' effect, the coefficient of HONEYMOON should be negative and statistically significant. Results (not reported) show that the effect of HONEYMOONis not statistically significant for either GCMO or NGCMO. Coefficients and significance levels ofTENURE and control variables remain largely unchanged. Therefore a 'honeymoon' effect in the Spanish audit market is rejected. 


\section{Additional results: controlling for accounting quality}

Both, the univariate and multivariate analyses indicate that the likelihood of NGCMO decreases with tenure. This finding suggests a loss of independence in long-term audit engagements. Thus, in order to enhance independence the mandatory rotation of the audit firm should be considered ${ }^{7}$. Nevertheless, following the classical definition of audit quality provided by DeAngelo (1981), there is an alternative explanation for the reported negative relationship between tenure and audit qualifications. As the ability to detect misstatements is higher when the auditor has a better client's knowledge, and given that this knowledge increases with tenure, it could be argued that the reported negative effect of tenure on NGCMO is not the result of lower independence but of higher accounting quality achieved in lengthy engagements. Furthermore, under the latter interpretation, the implications for policy makers would be completely different: mandatory rotation would impoverishaccounting quality. Vanstraelen's (2000) previous research reporting a negative effect of tenure on the likelihood of audit qualifications did not control for accounting quality. Therefore, her main conclusion suggesting a loss of independence in extended audit contracts could be misleading, since it could be alternatively explained by higher levels of accounting quality achieved in lengthy engagements. 


\begin{tabular}{|c|c|c|c|}
\hline & Predicted sign & NGCMO (Z-value) & GCMO (Z-value) \\
\hline PBANK & + & $\begin{array}{c}0.06 \\
(1.76)\end{array}$ & $\begin{array}{c}0.11 * * \\
(3.44)\end{array}$ \\
\hline SIZE & - & $\begin{array}{l}-0.84 * * \\
(-2.77)\end{array}$ & $\begin{array}{c}-0.65 \\
(-1.26)\end{array}$ \\
\hline LEVERAGE & + & $\begin{array}{l}0.47 * \\
(2.31)\end{array}$ & $\begin{array}{c}0.68 * * \\
(3.66)\end{array}$ \\
\hline LIQUIDITY & - & $\begin{array}{l}-5.57 * * \\
(-3.72)\end{array}$ & $\begin{array}{l}-22.69 * \\
(-2.47)\end{array}$ \\
\hline STOCKS & + & $\begin{array}{c}-1.14 \\
(-0.95)\end{array}$ & $\begin{array}{c}1.84 \\
(0.96)\end{array}$ \\
\hline LOSSES & + & $\begin{array}{c}0.59 \\
(1.60)\end{array}$ & $\begin{array}{c}3.00 * * \\
(4.36)\end{array}$ \\
\hline CRISIS & + & $\begin{array}{c}-0.02 \\
(-0.05)\end{array}$ & $\begin{array}{c}2.34 * * \\
(2.77)\end{array}$ \\
\hline AUDFIRM & - & $\begin{array}{c}-0.94 \\
(-1.81)\end{array}$ & $\begin{array}{c}-1.61 \\
(-0.65)\end{array}$ \\
\hline TENURE & - & $\begin{array}{c}-0.49 * * \\
(-2.70)\end{array}$ & $\begin{array}{c}0.28 \\
(0.54)\end{array}$ \\
\hline ACCRUALS & + & $\begin{array}{c}-0.09 \\
(-0.14)\end{array}$ & $\begin{array}{c}0.02 \\
(0.01)\end{array}$ \\
\hline INTERCEPT & & $\begin{array}{c}1.13 \\
(1.10)\end{array}$ & $\begin{array}{c}-4.96 \\
(-1.76)\end{array}$ \\
\hline $\mathrm{N}$ & \multicolumn{3}{|c|}{610} \\
\hline Chi-Square & \multicolumn{3}{|c|}{$165.31^{* *}$} \\
\hline Pseudo $\mathrm{R}^{2}$ & & 0.3032 & \\
\hline
\end{tabular}

*,** Significant at the 5 percent and 1 percent levels, respectively

Table 6. Regressions results on the association of tenure with auditor's opinion, controlling for accounting quality

High levels of accruals are usually associated to high levels of earnings management and therefore to poor accounting quality (e.g., Bradshaw et al., 2001; Myers et al., 2003). If the negative relationship between tenure and NGCMO is explained by higher accounting quality associated to longer tenures, once accruals are included in the model, TENURE should not significantly affect the likelihood of NGCMO. Conversely, if the effect of TENURE remains negative after controlling for accounting quality, our main conclusion that longer tenures make NGCMO less likely would not be explained by changes in accounting quality, and thus, the alternative explanation of a loss of independence in long- 
term engagements would prevail. We compute the firm's total accruals (ACCRUALS) as the absolute value of the difference between operating income and cash flows from operations, scaled by lagged total assets. Data is obtained from the Thomson Reuters Knowledge database. The Pearson's correlation coefficient between ACCRUALS and TENURE is -0.125 and it is statistically significant $(P$-Value $<0.01)$, thus, suggesting higher accounting quality in longer tenures. We include the new variable $A C C R U A L S$ in model 1 to obtain model 2.

Model 2:

OPINION = f (PBANK, SIZE, LEVERAGE, LIQUIDITY, STOCKS, LOSSES, AUDFIRM, CRISIS, TENURE, ACCRUALS)

Table 6 shows the estimates of model 2. After removing those observations without data for the new variable $A C C R U A L S$, the sample size drops to 610 firm-year observations. As a proof of robustness, results do not change much with this subsample compared with those reported in table 5 with the whole sample. The model's pseudo $\mathrm{R}^{2}$ increases from $23 \%$ to $30 \%$ and coefficients and significance levels for control variables are largely unchanged $^{8}$. Focusing on NGCMO, the coefficient of TENURE remains negative and statistically significant $(P$-Value $<0.01$ ) while the coefficient of ACCRUALS is negative but non-significant. Accordingly, our main previous finding that the likelihood of NGCMO decreases with tenure is robust to the inclusion of accounting quality in the model. Thus, we rule out that the explanation of the relatively lower probability of audit qualifications associated to long-term engagements could be an increase in accounting quality. Therefore, our empirical evidence supports that independence is impaired in longer tenures.

\section{Conclusions}

Supporting the concern expressed by the Green Paper on Audit Policy, long-term engagements seem to compromise the independence of external auditors in the Spanish low litigation risk audit market. Besides, consistent with the litigation risk framework, auditors seem to be willing to compromise independence in lengthy engagements regarding relatively low-risk NGCMO, but not about high-risk GCMO. These findings, in conjunction with the available evidence for the US high litigation risk market, mostly 
failing to support a negative effect of tenure on auditor independence, strengthen the soundness of the litigation risk framework to explain auditor's reporting decisions.

This research shows that auditors seem willing to sacrifice independence in lengthy engagements, but only regarding the issuance of NGCMO.This result might have some interesting implications for policy makers, particularly in the current discussion about the necessity of mandatory audit firm rotation. If, as most papers do, we measure auditor independence only through the issuance of GCMO, a mandatory firm rotation rule does not seem to be necessary. However, if we take into account all types of audit qualifications, a mandatory rotation rule could increase independence. Although our findings support a mandatory rotation rule at a firm level in order to strengthen the value of audit reports for external users, the negative potential effects of such a rule, for example on the costs of audits, would require a more careful analysis.

The tests performed support our multinomial approach over classical bivariate logistic models. Moreover, results are consistent with the different implications of GCMO and NGCMO on the litigation risk faced by the auditor, and cannot be explained by higher levels of accounting quality supposedly achieved in longer tenures. Therefore, a natural extension of this research would be to re-examine available international evidence at the light of this new approach. In addition, given the serious concern about the negative effects of tenure on independence expressed by the European Commission and the different levels of litigation risk within the European Union, a multi-country research with a European focus would be particularly meaningful.

The most important limitation of this research is due to the uncommonness of GCMO in our sample. Since our conclusions regarding GCMO are based on a too low number of qualified reports, they should be carefully taken. In such a case, the reported results are too dependent on particular observations and the effect of a given variable in the model could more easily be captured by another variable, making results to be misleading. 


\section{NOTES}

${ }^{1}$ Although most countries only require the rotation of the lead audit partner, Italy, Brazil and South Korea have enforced a mandatory rotation rule for the audit company. In Austria, Canada and Spain, a mandatory company rotation rule was enforced, but subsequently abandoned.

${ }^{2}(\ldots)$ in the critical area of fair value reporting of financial instruments, instead of skeptically testing the reasonableness of managements' assumptions and resulting assertions, one firm's method involved obtaining valuations from a number of external parties and picking the one that is, 'closest to the pin' - the pin being management's claimed value (Doty, 2012).

${ }^{3}$ This shortcoming was explicitly pointed out by Hopwood et al. (1994) by stressing the importance of carrying out research on the auditor's reporting decision in contexts different than the Anglo-American.

${ }^{4}$ This point was clearly posed by Menon and Williams (2010: 2): "Auditors have expertise in assurance audits, not in judging the going concern status of a firm, and their assessment may not add to what investors already know.",

${ }^{5}$ Under the new Audit Law, uncertainties about the continuation of business do not motivate a qualified opinion, but a paragraph of emphasis. However, as our research period ends before the enforcement of the new Law, this difference treatment of uncertainties will not affect our results.

${ }^{6}$ When the audit report contains both types of audit qualifications, due to the particularly serious implications of GCMO, it has been coded 2.

${ }^{7}$ However, the potential benefits of establishing a mandatory audit firm rotation rule should be balanced with the increase in the costs for the audit sector and for the whole economy of such a rule.

${ }^{8}$ The main differences with results reported in table 5 are that variable AUDFIRM and LOSSES are no longer statistically significant for NGCMO. 


\section{REFERENCES}

Ameen, E.C., Chan, K. and Guffey, D.M. (1994). Information content of qualified audit opinions for overthe-counter firms. Journal of Business Finance and Accounting, 21, 997-1011.

Ball, R., Walker, R.G. and Whittred, G.P. (1979). Audit qualifications and share prices. Abacus, 15 (1), 23 34.

Bradshaw, M., Richardson, S. and Sloan, R. (2001). Do analysts and auditors use information in accruals? Journal of Accounting Research, 39 (1), 45-74.

Butler, M., Leone, A. and Willenborg, M. (2004).An empirical analysis of auditor reporting and its association with abnormal accruals. Journal of Accounting and Economics, 37, 139-165.

Carcello, J.V., Hermanson, D.R. and Huss, H.F. (1995). Temporal changes in bankruptcy- related reporting. Auditing. Journal of Practice and Theory, 14 (2), 133-143.

Carcello, J.V.and Neal, T. (2000). Audit committee composition and auditor reporting. The Accounting Review, 75 (4), 453-467.

Carey, P.J. and Simnett, R. (2006). Audit partner tenure and audit quality. The Accounting Review, 81 (3), 653-676.

Chen. P.F. He, S. Ma, Z. and Stice, D.E. (2012). Qualified audit opinions and debt contracting. Working Paper (Kobe University).

Choi, S. and Jeter, D. (1992). The effects of qualified audit opinions on earnings response coefficients. Journal of Accounting and Economics, 15 (2-3), 229-247.

Chow, C.W. and Rice, S.J. (1982). Qualified audit opinions and auditor switching. The Accounting Review, 57 (2), 326-335.

Chow, C.W. and Rice, S.J. (1982b). Qualified audit opinions and share prices - An investigation. Auditing: A Journal of Practice and Theory, 1 (2), 35-53.

CNMV (Comisión Nacional del Mercado de Valores) (2009). Report on the Review of the Annual Financial Reports Filed with the CNMV, Madrid, Spain.

Craswell, A.T. (1988). The association between qualified opinions and auditor switches. Accounting and Business Research, 19, 23-31.

De Angelo, L. (1981). Auditor size and audit quality. Journal of Accounting and Economics, 3 (3), 183199.

DeFond, M., Raghunandan, K. and Subramanyam, K.R. (2002). Do nonaudit service fees impair auditor independence? Evidence from going-concern audit opinions. Journal of Accounting Research, 40 (4), $1247-1274$

Directive 2006/43/EC of the European Parliament and of the Council of 17 May 2006 on statutory audits of annual accounts and consolidated accounts, OJ L157/2006 p.87 (2006).

Dopuch, N., Holthausen, R. and Leftwich, R. (1987). Predicting audit qualifications with financial and market variables. The Accounting Review, 62 (3), 431-454.

Doty, J. (2012). The relevance of audits and the needs of investors. SEC and Financial Reporting Institute 31st Annual Conference: May 31.

European Commission (EC) (2010). Audit policy: Lessons from the crisis. Green Paper (Brussels). 
Firth, M. (2002). Auditor-provided consultancy services and their associations with audit fees and audit opinion. Journal of Business Finance and Accounting, 29 (5-6), 661-693.

Firth, M., Oliver, M. and Wu, X. (2012). How do various forms of auditor rotation affect audit quality? Evidence from China. The International Journal of Accounting, 47 (1), 109-138.

General Accounting Office (GAO) (2003). Required study on the potential effects of mandatory audit firm rotation, United States General Accounting Office.

Gul, F., Basioudis, I. and Ng, A. (2011). Non audit fees, auditor tenure and auditor independence. International Symposium on Audit Research (ISAR).

Hopwood, W. McKeown, J.C. and Mutchler, J. (1989). A test of the incremental explanatory power of opinions qualified for consistency and uncertainty. The Accounting Review, 64 (1), 28-48.

Hopwood, W. McKeown, J.C. and Mutchler, J. (1994).A reexamination of auditor versus model accuracy within the context of the going-concern opinion decision. Contemporary Accounting Research, 10 (2), 409431.

Knechel, W. and Vanstraelen, A. (2007). The relationship between auditor tenure and audit quality implied by going-concern opinions. Auditing: A Journal of Practice and Theory, 26 (1), 113-131.

Krishnan, J. (1994). Auditor switching and conservatism. The Accounting Review, 69 (1), 200-215.

Krishnan, J. and Krishnan, J. (1997). Litigation risk and auditor resignations. The Accounting Review, 72 (4), 53960 .

Lennox, C. (2000). Do companies successfully engage in opinion-shopping? Evidence from the UK. Journal of Accounting and Economics, 29 (3), 321-337.

Levinthal, D.A. and Fichman, M. (1988). Dynamics of interorganizational attachments: auditor client attachments. Administrative Science Quarterly, 33 (3), 345-369.

Lim, C. and Tan, H. (2010). Does auditor tenure improve audit quality? Moderating effects of industry specialization and fee dependence. Contemporary Accounting Research, 27(3), 923-957.

Loudder, M., Khurana, I., Sawyers, R., Cordery, C., Johnson, C., Lowe, J. and Wunderle, R. (1992). The information content of audit qualifications. Auditing: A Journal of Practice and Theory, 11 (1), 69-82.

Louwers, T. (1998). The relation between going-concern opinions and the auditor's loss function. Journal of Accounting Research, 36 (1), 143-156.

Lys, T. and Watts, R.L. (1994). Lawsuits against auditors. Journal of Accounting Research, 32, 65-93.

Mautz, R.K. and Sharaf, H.A. (1961). The Philosophy of Auditing. Sarasota, FL: American Accounting Association.

McDaniel, L.S. (1990). The effects of time pressure and audit program structure on audit performance. Journal of Accounting Research, 28 (2), 267-285.

Melumad, N. and Thoman, L. (1990). On auditors and the courts in an adverse selection setting. Journal of Accounting Research, 28 (1), 77-120.

Menon, K. and Williams, D. (2010). Investor reaction to going concern audit reports. The Accounting Review, 85 (6), 2075-2105.

Myers, J., Myers, L. and Omer, T. (2003). Exploring the terms of the auditor-client relationship and the quality of earnings: A case for mandatory auditor rotation? The Accounting Review, 78 (3), 779-799. 
Myers, J., Myers, L., Palmrose, V. and Scholz, S. (2005).The length of auditor-client relationships and financial statement restatements. Working Paper, Texas A\&M University.

Narayanan, V. (1994). An analysis of auditor liability rules. Journal of Accounting Research, 32 (supplement), 39-64.

Palmrose, V. (1987). Litigation and independent auditors: the role of business failures and management fraud. Auditing: A Journal of Practice and Theory, 6 (2), 90-102.

Public Company Accounting Oversight Board (PCAOB) (2011). Improving the transparency of audits: Proposed amendments to PCAOB auditing standards and Form 2. PCAOB Release No. 2011-007.

Ruiz-Barbadillo, E., Gómez-Aguilar, N. and Biedma, E. (2005). Análisis empírico del efecto de la duración del contrato de auditoria en la recepción de informes cualificados. Revista de Contabilidad, 8 (16), 15-39.

Ruiz-Barbadillo, E., Gomez Aguilar, N. and Carrera, N. (2006). Evidencia empírica sobre el efecto de la duración del contrato en la calidad de la auditoría: análisis de las medidas de retención y rotación obligatoria de auditores. Investigaciones Económicas, 30 (2), 283-316.

Ruiz-Barbadillo, E., Gomez Aguilar, N., De Fuentes-Barberá, C. and García Benau, M.A. (2004). Audit quality and the going-concern decision making process: Spanish evidence. European Accounting Review, $13(4), 597-620$.

St. Pierre, K. and Anderson, J. (1984). An analysis of the factors associated with lawsuits against public accountants. The Accounting Review, 59 (2), 242-263.

Shockley, R.A. (1982). Perceptions of audit independence: a conceptual model. Journal of Accounting, Auditing and Finance, 5, $126-143$.

Shu, S. (2000). Auditor resignations: clientele effects and legal liability. Journal of Accounting and Economics, 29 (2), 173-205.

Simunic, D.A. (1980). The pricing of audit services: theory and evidence. Journal of Accounting Research, 18 (1), 161-190.

Simunic, D.A. (1984). Auditing, consulting, and auditor independence. Journal of Accounting Research, $22(2), 679-702$.

Sutton, M.H. (1997). Auditor independence: The challenge of fact and appearance. Accounting Horizons, $11(1), 86-91$.

Vanstraelen, A. (2000). Impact of renewable long-term audit mandates on audit quality. European Accounting Review, 9 (3), 419-442.

Vanstraelen, A. (2002). Auditor economic incentives and going-concern opinions in a limited litigious continental European business environment: empirical evidence from Belgium. Accounting and Business Research, 32 (3), 171-186.

Zmijewski, M.E. (1984). Methodological issues related to the estimation of financial distress prediction models. Journal of Accounting Research, 22 (Supplement), 50-58. 